\title{
Innovation Environment in Small Technology-Based Companies
}

\author{
Gabriela Gonçalves Silveira Fiates', José Eduardo Azevedo Fiates², Fernando A. Ribeiro Serra ${ }^{3}$, \\ Manuel Portugal Ferreira ${ }^{4}$
}

\begin{abstract}
Innovation has been identified as a strategy to achieve competitive advantage, particularly in contexts of change and especially for technology-based companies - TBCs. Although the adoption of innovation strategies is not easy, small companies have an organizational environment more conducive to innovation. This article examines how managers and employees of small TBCs perceive aspects of the internal environment of innovation in the organization (culture, organizational structure, personnel and infrastructure) and their suitability for the innovation process. This is a qualitative research from a multicase study on five companies located in an incubator. Data were collected through open interviews, using a semi-structured script, with one of the managers and two employees from each company. Data were analyzed from preliminary content analysis. The results showed some discrepancies between the perceptions of managers and employees about the issues investigated and their suitability for the innovation system, as well as between reality and the theoretical basis used.
\end{abstract}

Key words: innovation; technology companies; incubators; multicase.

\footnotetext{
' Unisul Business School. Universidade do Sul de Santa Catarina Rua Trajano, 219. Centro - Florianópolis - SC. Tel: 48-3229I9I4. Email: gabriela.fiates@unisul.br

${ }^{2}$ Fundação Certi. Cidade Universitária - Caixa Postal 5053. 88040-970 - Florianópolis - SC. Tel: 48-32392I 50. Email: jef@certi.org.br

${ }^{3}$ Unisul Business School. Universidade do Sul de Santa Catarina. Rua Trajano, 219. Centro - Florianópolis - SC.

Tel: 48-32291914. Email: fernando.serra@unisul.br

${ }^{4}$ Escola Superior de Tecnologia e Gestão. Instituto Politécnico de Leiria. Morro do Lena - Alto Vieiro. Leiria - Portugal.

Tel: 48-3229/9|4. Email: portugal@estg.ipleiria.pt
} 


\section{Introduction}

The increasing competitiveness and mimicry or imitation by competitors, is responded with more innovative efforts by companies. The scientific and technological advances reduce the life cycle of products and services requiring the ability of companies to monitor and incorporate innovations in all levels. In this context, innovation is cited as the difference that organizations should pursue to achieve stronger levels of competitiveness. The search and development of innovations and knowledge are among the main sources that support the position of organizations in the market (Grant, 1996; Christensen, 200I, Kotler and Keller 2005). In recent research, Malachias and Meirelles (2009) showed that the environment for innovation and the technological system determine the innovative profile, and this profile influences the business performance.

The real innovation differential is consolidated in the organizational culture and is present in the entire company, while innovation can be targeted to specific aspects of the products, services or new markets (Tucker, 2002). Tidd, Bessant and Pavitt (200I) also considered innovation as a strategy that cannot be adopted partially in the organization, since it is the result of collective and continuing efforts of all areas, not only those of research and development.

Despite the recognized importance of innovation to organizational competitiveness and economic development, Brazilian industry data show that innovation grows very slowly in the country. According to IBGE'S Industrial Research on Technological Innovation, presented by the National Association for Research, Development and Engineering of Innovative Companies (Anpei, 2006), innovation rate in Brazilian industries increased from $31.5 \%$ between 1998 and 2000 to $33.3 \%$ between 2000 and 2003, which represent only 1.8 percentage points. According to the survey, this increase is due mainly to the action of small and medium enterprises.

According to Christensen (200I), small companies are more innovative, or at least have an organizational environment more conducive to innovation. Quinn (1985) argues that small companies are more innovative because they are driven by necessity. Small businesses are often founded due to new technology, they are visionary, have a flat structure, low operating costs, and thus are more flexible and quick to adopt new products, technologies and processes. However, despite the supposed easy to innovate because of the deficiencies they present (financial, managerial and personnel), it is just the smaller companies that have greater difficulties in relation to innovation activities (Maculan, 2003). It seems that small entrepreneurial companies face several challenges in commercialising their innovations. (Oksanen and Rilla, 2009). Thus, overcoming the difficulties requires joint efforts by managers and employees to develop an innovation-friendly environment that generates real commitment to pursuing competitive advantage.

In this context, the objective of this study is to examine how managers and employees of small technology-based companies (TBCs) perceive aspects of the internal environment of the organization and their suitability for the innovation process. This article is intended to contribute to the theoretical growth of the area and clarify the innovation process in small businesses seeking to identify elements in the organizational environment that are perceived as catalysts of the innovation process. Points of disagreement between managers and employees regarding innovation are also sought. This article is based on a qualitative study of five technology-based small companies, located in a business incubator. Data were collected through open interviews, using a semi-structured script, with one of the managers (the founding member) and two employees from each company. Data were analyzed from preliminary content analysis.

The remaining part of the article is organized into four parts. Following are the theoretical aspects underpinning the study, the methodological procedures, the presentation and data analysis, and the closing remarks.

\section{Review of the Literature}

Today, perhaps more than in past decades, executives suffer increasing pressure to anticipate and respond to external forces. The increasing globalization, intensifying competition, new product concepts and processes, lower life cycle of products, flexibility in responding to the market, industrial automation, new raw materials and changing patterns of production organization are some of the elements that make up the so-called new competition, which opposes the widespread availability of standardized products. 
According to Christensen (200I), in today's economy, innovation is the main driver for increased competitiveness and superior economic performance of the company. Companies have had to continually adapt to the context in which innovation has taken form as a real differential to companies wishing to remain competitive. Innovation is thus an essential element in business strategy to achieve competitive advantage in turbulent environments. In other words, the competitiveness of firms depends not only on their ability to adapt to the changing environment in which they operate. To deal with the turbulence, companies should go ahead, innovate and transform (Motta, 200I). "Formulating and implementing a broad innovation strategy is the key to sustaining competitiveness" (Alijani, 2009, p. II5).

Innovation is not simply generating new products. Seen more broadly, innovation can be defined as the process of creating something new with a value to an individual, group, organization, industry or company (Higgins, 1995). Innovation must have also a multidisciplinary character because, as stated by Sawhney and Wolkott (2006, p.77), "Innovation is the creation of new substantial or radical values to consumers and businesses through the dramatic alteration of one or more dimensions of existing business systems or by setting up completely new business". And, according to Neely and Hii (1998), the effect of innovation is to transform the internal capabilities of the organization, making it more flexible and able to learn and explore new ideas. At corporate level, innovation is primarily related to learning, change, risk and cost (Tidd, Bressant and Pavitt, 200I).

In today's world, improvements and novelties come every week from some emerging market, some cutting-edge technological development, some unusual form of marketing, among other innovations. These new offers and technologies result in new opportunities for which we should be prepared to understand and take advantage. Developing a knowledge base is imperative to deal with them. Berkun (2010) states that an innovation results always from a good knowledge that is based on lived experiences.

New strategies, new processes or new tools, all create the need for many people to learn new things (Starkey, 1997). Learning, in turn, becomes increasingly an essential factor for the ability to innovate. This learning process is double folded: part one occurs internally in the company and represents the completion of R\&D activities and setting routines and procedures; part two results from the interactions of firms with foreign partners: suppliers or users of goods and services, research centers, government agencies, trade associations, among others. These interactions contribute significantly to the definition of innovation (Lundvall, 1992).

Learning which aims innovation as a result is not merely reactive, but intentional, effective and connected to the objective and strategy of the organization. Thus, the organization which learns becomes not only able to adapt and survive the changes and unpredictability, but despite them define its future. Learning creates flexibility and agility for the organization to deal with uncertainty, allowing the analysis of different possibilities. Learning creates a creative, innovative and entrepreneurial environment (Fiates, 200I; Starkey, 1997; Lundvall, 1992).

The elements and relations present in a system may determine the learning capacity of a country, region or locality, and therefore the ability to innovate and adapt to environment changes (Lundvall, 1992).

The development of an attitude toward learning and evidence of this importance for the principles, philosophy, profile of employees, infrastructure and organizational structure, is essential for businesses. Cândido and Oliveira (2007) confirm that the development of innovative capacity of organizations is related to an innovation-friendly environment, encompassing organizational aspects such as organizational structure, people, physical and cultural environment in addition to customer focus, training partnerships, an efficient communication and organizational learning. We will see these factors below.

\section{Innovation-Friendly Environment}

Several internal and external factors can positively or negatively influence the development of innovations (Barbieri et al., 2004). Traditionally, external environmental factors indicated as conditioning for the innovation environment are: market structure, firm size, degree of industry concentration, entry and exit barriers, and macroeconomic factors, among others. According to Maciel (1996, p. 109), the "innovation environment refers, therefore, to the set of political, economic, social and 
cultural factors that stimulate or hinder innovation." Despite the importance of the external environment, this study limits itself to the analysis to the company internal factors.

Internal factors may include both physical and organizational aspects. For example, Mendel (2004) presented the following determinant factors for organizational innovation: the strategy of new products and services for the construction of competitive advantage; favorable physical environment; clear and fluid communication; flexible organizational structure; team working (confidence); freedom and autonomy; participation; management activities that encourage employee participation, recognition and reward; training and development; resource availability; and organizational learning to disseminate tacit knowledge and new knowledge.

Leonard-Barton (1998) argued for more factors related to people, pointing out that innovation comes from the ability to learn from the professionals that make up the organization, through the interaction between them and knowledge sharing, i.e. the ability to learn, which defines the character of innovation. An innovative organization needs innovative people and, according to Tucker (2002), it is important for people to have freedom and autonomy to foster innovative efforts. Innovation culture cannot nurture fears to take risks, because even errors are part of the learning process. Barbieri (2004) also focused on factors related to people management, including elements such as motivation, job satisfaction, creativity stimulation, conflict reduction within the management, leadership, internal communication, innovative project management, internal entrepreneurship, reward systems, and innovative climate. According to the author, all these are present in management models of innovative organizations.

Neely and Hii (1998) emphasize the role of culture and organizational structure in a network to promote innovation. Organizational culture and climate encourage a collaborative behavior among all employees. Sluis (2004) also focuses on the role of culture and climate, but highlights, in addition, the role of managers as key drivers for innovation in the organization. Sluis (2004) also reinforces that these three elements are supported by learning and teamwork.
The organizational structure was identified as one of the determinant factors for the innovation process. Burn and Stalker (196I) and Mintzberg and Quinn (200I), for example, state that highly structured organizations with division of work and routines described in detail and rigid chain of command are not adequate for organizations in very dynamic environments. That is, they are not favorable to change and innovation. Thus, an innovative organization should not be overly formalized.

In short, the previous literature review allows us to agreeing to four components in an environment conducive to innovation, which include: culture, organizational structure, personnel and infrastructure. The convergence of these components seems to characterize an organizational environment that promotes learning and generates significant innovations.

Organizational culture is understood in this study as the result of a socially constructed learning process. Schein (1986) defines culture as the learning product through common experience of a group, although several different "cultures" may coexist in an organization. The author argues that culture is learned and can be developed with experience. Culture is not something imposed on a social situation; rather it develops in social interactions.

Organizational culture is formed in the socialization and internalization of codes and collective cultural patterns which can be modified and lead to innovation because they are seen as resulting from a natural learning process. In this context, any change in the way of doing things is based on a cultural shift that reflects new values, beliefs and principles, which can encourage and sustain this new organization. A culture focused on innovation particularly values knowledge acquisition and creation. A culture focused on innovation is characterized by its innovative vision of the future, openness to new experience, acceptance of calculated risks, recognition of errors and failures, and the need to continually learn from the experience (Neely and Hii, 1998; Sluis, 2004; Tucker, 2002).

The organizational structure can be defined as how members of a company are grouped and relate to performing tasks for which they are responsible (Foguel and Souza, 1985). In other words, the structure includes elements such as the hierarchical structure of the company, the division of tasks, 
the involvement and responsibility of individuals, organizational culture, leadership and power structure within the company. In this sense, a company that seeks continuous innovation may present an organizational structure different from a traditional business. In fact, there is no single model that represents an ideal structure for innovation, because the essence is just having one which is flexible and easily adaptable to situational demands. In this context, virtual enterprises, business networking, matrix models and even the absence of formal structure arise. However, whatever option is chosen, fluidity, flexibility and freedom of interaction between the various levels and subjects are the most important aspects. It should be noted that innovation flows more easily in fluid and horizontal structures, without so many hierarchical levels. Janov (1996, p. 22) reinforces this idea, noting that:

What we need most today are organizational structures and hierarchies that exist only to unite various efforts, not to confer status. When our status derives from our position in the hierarchy, we focus on preserving our status and not serve the whole system. Preserving status = preserving the status quo.

This sense of preservation expressed by Janov (1886) is exactly the opposite of the proposed dynamics of innovation. Regarding labor division, emphasis is placed on teams, in particular on multifunctional teams with common interests and knowledge relations that complement each other. These teams tend to do well in challenging situations that encourage the use of their full potential. With respect to the power structure, it is important to emphasize that it is not possible to establish an innovation supportive culture and re-conceptualize the organizational structure of a company without a profound change in the very sense that power represent in the organization. In the traditional organization, power is inherent to the person's position and information is often considered a source of individual power. This mentality does not match the profile of an innovative organization, in which knowledge fuels innovation. Innovative companies disseminate information to create knowledge, delegate authority and decisionmaking power to harness the creative and innovative potential of individuals (Fiates, 200I; Barbieri, 2003; Burn and Stalker, 2003).
With regarding to personnel, the third component analyzed, it can be said that companies create environment conducive to innovation, but there are the individuals who have the capacity or ability to learn and do something new. People are the spirit of the organization that learns and innovates. And people have free will, a mind of its own and unique way of thinking. What companies sometimes overlook is that individuals must be fully included in the organization to find some legitimacy in what they do and encounter motivation to produce, innovate and learn from their experiences (Ramos, 1983).

The development of creative and innovative potential of employees involves the ability to act in various situations to create new ideas and ways of working, which translates into decisions and actions, i.e., increases the autonomy and self-realization of individuals and generate true results for the company. It is important to remember that successful organizations are flexible, innovative and effective because their people are. In this sense, people need to be motivated to innovate and need an inspirational leader who is the maestro of the innovation process (LeonardBarton, 1992; Fiates, 200I, Barbieri, 2003; Mendel, 2004).

Infrastructure, the fourth component under analysis, is important because it allows people to maximize their innovative potential through learning, providing favorable conditions for the acquisition of data and information to be transformed into knowledge. The physical environment should provide interaction between people, through an open layout, making use of common spaces. It is also interesting to have technological support to create longterm value. Although it is not a mandatory condition for innovation, access to technology amplifies the company's innovative capacity (Amabile, 1996; Fiates, 200I; Barbieri, 2003; Mendel, 2004).

The development of innovative potential of a company depends on the compliance with some aspects of the internal environment in order to break down barriers and foster a truly innovative culture. As described earlier, convergence and coherence between the four organizational components are important to enhance the results of the learning process and the company's success on the market.

The methodology section presented below seeks to verify the perception of managers and employees of five small 
technology-based companies (TBCs) in relation to the organization internal environment and its suitability for the innovation process, as mentioned in the literature review presented earlier as: recognition of innovation importance; organizational culture; organizational structure; personnel; and infrastructure.

\section{Methodology}

This is a multicase study, based on the analysis performed in five small technology-based companies (TBCs), installed in a business incubator. The selection of the companies was intentional and sought cases in which, at least theoretically, innovation strategy could be viewed as essential. This decision was based on the assumption that "generalization, in the statistical sense, is not the goal of qualitative research (Merriam, 1998, p. 61). The choice of TBCs as a research field is based on the premise that innovation incorporation in these companies is of strategic importance for their survival and competitiveness. The TBCs take the risk of innovative activities from the development of untested technologies in the market for new products and/or processes (Pinho et al., 2002). Business incubators are the mechanisms to stimulate the creation and development of micro and small enterprises, through complementary training of the entrepreneur in technical and management aspects. Furthermore, they facilitate and expedite the process of technological innovation in micro and small enterprises (PNI, 2007). In this study, each company was represented by three individuals, two employees and a founding partner.

Data collection was performed by means of individually performed open interviews, using a semi-structured script, which were recorded and later transcribed. The questions sought to identify observable features that could characterize the company's vision on innovation process, organizational environment and its suitability for the innovation process. For the interview instrument construction, four components of the organizational environment were taken into account, as described in the previous section and displayed in the following table:

\begin{tabular}{|l|l|}
\hline Components & Observable aspects \\
\hline $\begin{array}{l}\text { Importance } \\
\text { innovation }\end{array}$ & - Perception of the importance of partners \\
\hline & - Perception of the importance of employees \\
\hline $\begin{array}{l}\text { Organizational } \\
\text { culture }\end{array}$ & $\begin{array}{l}\text { - Shared Vision and Mission } \\
\text { - Values }\end{array}$ \\
& $\begin{array}{l}\text { - Enhancement of learning and knowledge and incentives } \\
\text { - Acceptance of mistakes }\end{array}$ \\
\hline - Collaborative and participatory environment \\
- Opportunities for experimentation
\end{tabular}




\begin{tabular}{|l|l|}
\hline \multirow{3}{*}{ Infrastructure } & $\begin{array}{l}\text { - Physical environment } \\
\text { - Access to new technologies }\end{array}$ \\
& $\begin{array}{l}\text { - Information and communication technologies Resources } \\
\text { available }\end{array}$ \\
\hline
\end{tabular}

Table I. Components of the organizational environment.

Source: Prepared by the authors.

The analysis of the collected data followed the preliminary content examination method, supported by the analysis of respondents' verbal communications. The aim was to obtain indicators that allow knowledge inference by extracting categories found in messages (Bardin, 1977). This method allowed the content of interviews to be explained, seeking to fully understand the message. It also helps identify whether observable aspects exist and the importance given to every aspect by the actors.

\section{Sample}

The five companies analyzed are installed in a business incubator in Florianopolis, Brazil. The incubator has all the physical infrastructure and management required for the development of TBCs. It offers communication and information technology, technical equipment for events and presentations, operational support services, bank agencies, post office, restaurants, financing search facilities, business intermediation, and other services to support business development. This incubator has received numerous national awards for its innovation support to incubated companies, serving as a reference for experiments of this kind in Brazil and abroad.

The five firms surveyed operate in the development of software and have the characteristics shown in Table 2.

\begin{tabular}{|l|l|l|l|l|}
\hline Company & Sector Operating & $\begin{array}{l}\text { Number of } \\
\text { employees }\end{array}$ & $\begin{array}{l}\text { Number of } \\
\text { products }\end{array}$ \\
\hline $\begin{array}{l}\text { Company } \\
\text { A }\end{array}$ & $\begin{array}{l}\text { Software and services for } \\
\text { project management and } \\
\text { software engineering. }\end{array}$ & 7 years & 6 & 1 \\
\hline $\begin{array}{l}\text { Company } \\
\text { B }\end{array}$ & $\begin{array}{l}\text { Specialized } \\
\text { Development for Engineering. } \\
\text { Training and consulting in } \\
\text { Hydraulics and Pneumatics. }\end{array}$ & 6 years & 5 & 2 \\
\hline $\begin{array}{l}\text { Company } \\
\text { C }\end{array}$ & $\begin{array}{l}\text { Software for public } \\
\text { administration. }\end{array}$ & 3 years & 8 & 5 \\
\hline $\begin{array}{l}\text { Company } \\
\text { D }\end{array}$ & $\begin{array}{l}\text { Software for advertising } \\
\text { agencies and management } \\
\text { tools. }\end{array}$ & 14 years & 30 & 2 \\
\hline $\begin{array}{l}\text { Company } \\
\text { E }\end{array}$ & $\begin{array}{l}\text { Communication Technology } \\
\text { and Signal Processing for } \\
\text { Sound, Image and Data. }\end{array}$ & 3 years & 8 & 2 \\
\hline
\end{tabular}

Table 2. General characteristics of the companies examined.

Source: Prepared by the authors.

It should be noted here that the time of the company's operation does not coincide, in most cases, with the incubation period. Some companies, such as those referred as $A, B$ and $D$, were created when the members were still in college. In the early years, some friends/partners worked together to develop a product linked to research projects developed at the university, with no managerial 
structure or commercial purpose. In all five cases, incubation time was less than five years.

Three individuals from each company, the founding partner and two employees, were interviewed. Of the 15 people interviewed, II had college degrees, including some with master's degree. All others were attending a course at university level. Of the 15 individuals, nine had degrees in engineering and the others in computer science. All 15 indviduals were in the $2 \mathrm{I}-38$ year age group.

\section{Results and Analysis}

Innovation relevance and the above mentioned four components are taken into account for the analysis of the results. The section is structured as follows:

\section{Regarding the Importance of Innovation}

When asked about the importance of innovation for the company, there was a consensus among partners and employees. They all believe that for a company in the sector in which they work be successful it must be innovative.

"In this business, if you are not innovative you will fail." (IE Employee)

"Nowadays, especially with the Internet, where you can find a number of free softwares, your product must have something else or it will not sell." (Company B Partner)

Regarding the innovative profile, all managers say they consider their company innovative, especially in the development of new products.

"Yes, because we seek innovative ways of doing things." (Company A Partner)

"Yes, because our focus is on new technologies." (Company B Partner)

"To be admitted to the incubator you have to show that your business plan is innovative, otherwise they will not accept you." (Company D Partner)

When the same question was made to employees, the answers were somewhat different. Although most consider the companies they work for innovative, some said that sometimes innovation is not a priority. Others were hesitant to classify the company as innovative.

"I know that the company must be innovative, but sometimes you have to do what they want you to do and that is it." (I E Employee)

"I'm not sure if we are innovative, we have only two products; will the improvements we have incorporated to them count?" (2 C Employee)

It can be observed that, in the speech of the Employee IE, the limitation of time and need to meet specific targets, including those agreed upon with the incubator in which they are located, lead sometimes to more controlled tasks, which can be perceived by employees as a lack of attention to innovation.

According to the Oslo Manual available at ANPEI (2006), a company can be classified as innovative if it launched at least one new product in the last three years. According to this concept, the analyzed companies could be considered innovative, because they all had some kind of innovation in this period. It should be noted that analyzing the list of products and services developed and the history of their development, we see a higher incidence of incremental innovations, i.e., the introduction of small improvements in the same product. But in all companies there is also the presence of breakthroughs, such as the new product launched by Company D, which was completely different from that achieved with its first product.

\section{Regarding the Organizational Culture}

Although entrepreneurs believe that the culture developed in the company is suitable for the promotion of innovative postures, all employees interviewed point out some diverging aspects experienced in practice, such as the difficulty to perceive that knowledge and learning are valued by the company; the absence of premiums and rewards; the lack of courses and opportunities for development; and lack of autonomy.

But when asked directly whether they considered the environment favorable to promoting innovation, almost all employees said yes, except for two of company $D$, who responded that not always it is so. They added that they 
do not feel safe to present new ideas, because they have to assume the inherent risks in this process. These issues denote that not always the culture desired by managers is recognized by the employees. But it is important to remember that culture is built by experienced practice. Culture is not something imposed on a situation, but rather developed during the course of social interaction. (Schein, 1986). It is apparent then that there is the need for managers to commit themselves to developing mechanisms that reinforce the desired culture, because, according to Tucker (2002), the climate in innovative organizations is easily perceived, since there are practices, procedures and rewards favorable to the adoption of innovative attitudes.

As to the mistakes committed in the course of their activities, most employees understand that they are part of the path that leads to good ideas, and that they learn from them. They also say that they are not afraid of being punished for making mistakes in innovative activities, for example in developing new applications or new features for existing products, but they feel that they cannot fail in routine activities, especially in those directed to customers, such as systems in use problem solving.

"I have some freedom to work on product improvement. I can innovate and make mistakes, but when I'm solving a specific problem, I have to do it right, because the client does not want me to solve his problem based on trial and error." (2 E Employee)

This attitude shows the individuals' maturity in relation to errors, because the process of active learning occurs from past experiences, especially with things that did not work, with past mistakes so that they will not happen again. This implies living naturally with the new error (in development and innovation processes), but not accepting the incidence of errors in routine activities, because these consist of repetitive activities already learned. (Starkey, 1997)

All managers say that the vision of the company's future is clear and well known by all. However, in two companies the employees interviewed were unaware of the existence of a vision, which does not contribute to developing an innovation culture. It is well known that a vision shared by all members is essential for the organization to be innovative, because it provides focus, direction and the required energy. (Nonaka and Takeuchi, 1997).

With regard to the availability of collaboration with other employees, there was also a consensus on the need for a collaborative environment and willingness to collaborate with others. Moreover, the employees point out that in practice there is not always cooperation, because everyone knows "what and how to do", so there is not much involvement.

"No one keeps asking if anyone wants to help, but if someone asks for, no one will deny it." (I D Employee)

It is perceived that collaboration is almost always a reactive action rather than a deliberate and natural action. Lundvall (1992) argues that cooperation between individuals is a unique opportunity for shared learning. If a collaborative environment is not fostered, great opportunities to innovate can be missing.

\section{Regarding the Organizational Structure}

Both managers and employees agree that, as companies are small, there are no rigid structures and all have few hierarchical levels. Few companies have formally structured areas: three of them, "one area" is represented by only one individual. In others, there is a division between the administrative and the production area. There is one, however, that has administrative financial area, commercial area (including office in another region) and operation area (development and production). Although they are small, their organizational structure is always presented as a classic pyramid.

"This organizational chart is only a scheme for everyone to understand who does what and who is the boss of whom. (...) It may not be ideal, but it is what I know and has always worked." (Company C Partner)

However, while managers believe that the existing structure is simple and very flexible, encouraging the process of horizontal and vertical communication, the employees disagree. The majority (eight out of ten employees interviewed) pointed out that, despite being small, the structure is rigid, divided into two levels - 
partners and employees - and that's why communication is essentially horizontal, but vertically very difficult. Partners seem to be unwilling to listen to the employees and are not always very clear in the dissemination of information.

As Tidd et al. (200I) emphasized it, the ability to innovate in a company requires the development of a set of skills and knowledge, not only in technology but also organizational and managerial. In the companies studied, managers have little managerial knowledge, because they have mainly technical education (engineering and/or computer science). So, they often end up adopting traditional management models because these are the only ones they know. However, to achieve competitive advantage from an innovation strategy it is essential to integrate capabilities of technological and organizational change to market expertise and to develop an internal management structure that meets the requirements of the innovation process in its various phases. (Maculan et al., 2002; Berkun, 2010).

Managers consider that the information is accessible to all and point to the Intranet and e-mail as the most used tools for information dissemination. The employees agree that the most used tools are the Intranet and e-mail, but complain about the lack of access to information, especially the strategic ones. They also complain about the lack of regular meetings and the lack of knowledge about the organizational objectives and goals.

"One of these days, I discovered by chance that we would export. Such an information is important because if there is a change in the market, shouldn't the product also change?" (2B Employee)

"I would like to know better what is expected of me." (IA Employee)

This aspect is contrary to a favorable environment for the development of innovations, because the flow of communication should be as much as debureaucratized as possible, so that there is freedom and transparency in the acquisition and dissemination of data and information. Exchanging experience and seeking knowledge where it can be found is of paramount importance (Fiates, 200I).

External communication is one of the strengths of the companies analyzed. Constant updating is a concern which leads people to seek knowledge from various external agents, such as other incubated TBCs, customers, suppliers, companies that provide management advice to incubated companies, SEBRAE, and especially the region's universities. Maculan et al. (2002) stresses that there must be external communication, i.e., organizations can and must share knowledge with one another to promote learning and innovation. This is very relevant, since the employees are seeking knowledge, even though they do not perceive the company's appreciation for the knowledge acquired. According to Leonard-Baton (1998), the competitive advantage of firms lies in their ability to develop innovations from external sources. The author adds that the only sources capable of meeting the technological shortcomings of the organizations are the universities, the research centers and other companies. This ease of interaction occurs in part because the companies are in an environment, different from the incubator, that in itself provides a network of relationships. Also, personal networks of entrepreneurs and their employees contribute to better interaction.

There are few formal attributions in the division of labor, which confers a certain degree of autonomy in the organization of the employee's work. In most companies, schedules are not rigid and people are organized by specific tasks or goals. Tasks can be classified as flexible, since formal procedures are almost absent.

This aspect is very positive and is consistent with the ideas of Burn and Stalker (cited in Barbieri, 2003) and Mintzberg and Quinn (200I) who stress the importance of flexibility in the structure and organization of work for the company to be able to perceive and take advantage of the opportunities for innovation.

Employees have also warned that although companies are small, have few employees, there is not always a collaborative environment between them. The predominant position is that in which everyone is responsible for a specific task and does not get involved with almost nothing but his own activities. Much is lost with this attitude, since they are all qualified and could certainly contribute more than they do individually. In innovative environments, teamwork provides greater flexibility to the company structure, since the teams are temporary. Thus, the company continuously redesigns its structure, or its list of teams, according to what is needed. 
Senge (1997) emphasizes that there is a need for innovative and coordinated action, and illustrates this type of action as those developed by sports teams or bands, in which there is a trustful operation so that each team member remains conscious of the other members and acts to complement their actions.

Employers say they do not promote specific opportunities for interaction among employees due to the low degree of departmentalization and the fact that the physical space of enterprises is limited. The company believes that interaction among employees occurs naturally. On the other hand, employees do not believe that the stress of daily activities will allow them to have trustful interaction, collaboration and learning from the exchange of experiences.

"We are in a daily rush, we have different schedules and each one is doing something different. Sometimes we even meet and exchange some ideas, but this is not always." (2 C Employee)

In four of the five companies examined there were no interaction or leisure activities scheduled by companies. The rare existing informal meetings are promoted by the employees. In the company there are a number of activities planned by management (to celebrate birthdays and other special dates) during which the employees take the opportunity to improve personal confidence and learn "who does what" and "what are the responsibilities of each one". Lundvall (1992) emphasizes the importance of interaction between the actors of the organization and the environment so that "learning by interacting" can be the starting point for the innovation process.

\section{Regarding People}

As to the policies of personnel management, both employers and employees agree that there are not differentiating policies. There is no compensation plan and employees feel the lack of recognition for their efforts and the ideas they bring to the company. They are no compensated for their contribution to product development, and small companies do not see the opportunities to grow:
"[...] we are collaborators and partners; if I am not one of the partners, I will always be only an employee." (I C Employee)

"I have mixed feelings, because while I want to give all of me in my work (developing and enhancing products), I keep thinking that this is not my business, this product is not mine, so why spend my ideas for others to have the profits? My true dream is to open my own business!" (I B Employee)

Society needs entrepreneurs to create new businesses and generate jobs and income, but also needs workers to make business grow. This is how economic development occurs. This requires that personnel management create an environment capable to attracting highly talented people and encouraging them to remain in the firm (Daft and Marcic, 2004). Talent retention depends on a policy that values human beings and be able to align personal objectives with organizational goals (Fiates, 200I). Lane et al (2010) have also discussed about the importance of promoting an environment and an organizational culture that support the team members in developing innovative behavior.

According to Tushman and Nadler (1997), alternatives such as bonds, shares, wages and promotions can be linked to innovation and development of new products and processes. The authors argue that the company should strengthen formal incentives to encourage innovative employees. In most of the analyzed companies, wages are fixed and there are no fringe benefits, but one is in the process of implementing a variable compensation system, with profit distribution. This company's employees are excited and full of expectations.

"I'm motivated. I think the company realized that we deserved more for what we do. I think I'm being respected, as more and more I do, more I'll get for it. "(I D Employee)

In addition, some employees complain about the lack of feedback on their results. Creativity, as key driver for innovation, may be compromised by the lack of positive reinforcement. It seems that creativity is encouraged when employees know that reward and recognition will happen when creative efforts are made. Rewards are linked to 
information about the competence of those involved and the value of their work (Amabile, 1996).

"I do not know exactly what is expected of me, because no matter what $I$ do no one tells me anything." (2 B Employee)

As for leadership, only employees were heard. Managers are identified as the organization leaders, and their commitment and "passion" are easily perceived. As the partners have expertise in the area operated by the company or because they helped develop the initial product, having the courage to open their own business, they are in most cases admired by the employees. Moreover, the employees admit that sometimes they do not know exactly what the organizational objectives are, since these are only in the "head of the owners." So, competence on personnel management is sometimes questioned:

"We do not have the autonomy to make decisions; they are the partners' job." ( I A Employee)

"I almost never have access to my superiors to offer feedback, suggestions and questions." (I E Employee)

It is important that leaders are legitimized by their competence. This is essential to create an environment in which human beings create new realities. Senge (1997) complements by saying that leaders have the responsibility of designing, guiding and teaching. They are responsible for building organizations where people continually expand their capacity to understand the dynamic complexity of the world, which involves defining goals and improving mental models.

As to the opportunities for development and training, employees claim that there are no plans for development or training offered by the company, but the incubator and SEBRAE always promote courses and lectures in which they always seek to participate. Furthermore, with the encouragement of the company, the employees also participate frequently in meetings and fairs. Tushman and Nadler (1997) emphasize the importance of continuing education programs for effective innovation. According to the authors, training programs, especially in different areas of their work, allow people to develop different perspectives, which no doubt fuels the innovation process.

\section{Regarding the Infra-Structure}

Everyone agrees that despite the limitation of space, the rooms offer adequate working conditions and the common areas provided by the incubator also offer privileged conditions for networking and technology access. This encourages innovation. According to Amabile (1996), access to safe and informal spaces facilitates creativity and encourages the participation of people in solving problems.

There is agreement between employers and employees that technologies available are always keeping up with the best and newest in their respective areas and to the extent that resources permit, they are always updated for the attainment of tasks. But as companies are small, they do not have enough funds to invest in management software, knowledge management and competitive intelligence. On the other hand, they themselves develop many applications to solve problems of everyday organizational issues.

To allow people in the organization to maximize their potential through learning, it is important to create all favorable conditions for data and information acquisition, processing it into knowledge, and its dissemination throughout the company. Fiates (200I) points out that access to new technologies can be a source for creating new ideas. In addition, the limited resources in the cases analyzed generate needs that end up inspiring innovation in support areas.

\section{Discussion and Final Considerations}

Due to the current dynamics and complexity of the environment, innovation has been mentioned by various authors as the best strategy to achieve competitive advantage. For TBCs, innovation is the main condition for survival. Regardless of their size, innovation is the cornerstone of these organizations. Hamel (2000) stated that the most important thing was not how they positioned in relation to some traditional rivals, but the creativity used to create new markets with their core competencies. Nonetheless, the adoption of an innovation culture is not an easy task because it depends on a supportive environment, creative people who are not afraid to make mistakes, resources for research, and a 
close interaction with the market and its actors, so as to perceive the existing opportunities.

Some authors argue that small companies have an organizational environment more conducive to innovation (Quinn, 1985; Christensen, 200I). However, Maculan (2003) points to the difficulties that small businesses suffer in trying to be innovative, because of the shortness of funds for administrative operations, financial management, personnel management, marketing, and sales. In the case of the five TBCs examined, these difficulties were present, but perhaps due to the focus of this study, personnel management was emphasized.

It is possible that the fact that these companies were incorporated in a technology-based incubator help minimize shortcomings and traditional deficiencies. The period during which such companies are incubated will allow a process of organizational and management learning resulting from the support mechanisms offered to the management and exchange of experiences with other incubated companies, access to technological information, contacts with government agencies or potential investors, research centers and participation in events sponsored by the incubator (Maculan et al. 2002; Maculan, 2003).

This study showed the importance of the manager role in the consolidation of an innovation strategy. The adoption and success of this strategy depend on the manger's vision, his ability to implement it and the resources available. Nidumolu, Prahalad and Rangaswami (2009) point that success often depends on executives' ability to create new mechanisms for innovating. This supports an entrepreneurial strategy, the most common form of innovation process in micro and small enterprises, where the figure of the entrepreneur and his motivation permeate throughout the organization (Mintzberg, Ahlstrand and Lampel, 2000). The literature review identified four key components for an environment conducive to innovation: culture, organizational structure, people and technology. The responsibility for innovation also requires the willingness of managers to action so that employees can together develop an innovation-friendly environment that generates real commitment to pursuing competitive advantage. Further research may explore other components and interactions between components, since it is not this author's intention to expose a comprehensive model here. The literature review pointed out other components and sub-components that may contribute to obtaining a more detailed view of internal dynamics in creating an innovative environment.

With respect to organizational culture, despite the willingness of managers, it could be seen that some employees do not perceive a culture conducive to innovation. The major differences between the perceptions of managers and employees was the difficulty in perceiving that knowledge and learning are valued by the company, in the absence of prizes and rewards; in the absence of courses and opportunities for development of individuals; in the lack of initiative to collaborate between them; in the lack of autonomy for decision-making; and in the partial knowledge of the organizational vision and objectives. Further research may also continue this methodological approach to evaluating how the perceptions of employers and employees differ and how these differences impact the innovation environment. Finding the roots of these differences is essential to provide an environment that can supports the innovation (Lane et al, 2010).

The analysis of the infrastructure component would seem to contradict the view which holds that in small firms, since having a simpler structure, are more flexible and conducive to learning and innovation. This study has shown that while their structure is flat and simple, perhaps due to the lack of more contemporary management models as a result of technical education, the models adopted repeat the traditional hierarchical structure. Also, management is centralized on the partner entrepreneurs, a fact that inhibits the communication and interaction process. Further empirical research can test hypotheses about the innovative performance of enterprises with more or less formalized and hierarchical structures.

This study showed that policies for personnel management were not perceived, probably due to lack of resources and knowledge in the area or because the small number of employees. This deficiency results in some discouragement, but in face of the challenge to innovate, the employees take on the responsibility to seek new knowledge in their external relations.

The infrastructure was adequate, according to the theoretical basis used. The lack of some resources does raise needs that, instead of provoking problems, are satisfied in an innovative way by the companies. It should 
be noted, however, that the cases examined are lodged in an incubator and they cannot, nor is it part of our scope, to isolate the effects of TBCs and the incubator. Thus, future research might explore the relative and comparative performance of TBCs in and out of incubators.

Focus on developing an environment that is conducive to innovation is of paramount importance when analyzing innovation as a strategy. Innovation is an inseparable process from the structure, behavior and culture of an organization. Although the companies analyzed are innovative, yet there are several aspects of the organizational environment that need improvement. Therefore, learning provided by the incubator environment can foster the development of skills, especially management, to improve its innovation potential and prepare TBCs for survival after the incubation phase.

\section{References}

ALIJANI, S. (2009). Pathways to Innovation: Evidence from Competitiveness Clusters in France. Oxford Journal, September, 8(I), I07-II8.

AMABILE, T. (1996) Managing for creativity. Course Note 9-396-27I. Harvard Business School, Feb. Boston,

ANPEI - Associação Nacional de Pesquisa (2003) Desenvolvimento e Engenharia das Empresas Inovadoras. Divulgação dados PINTEC 2003. http://www.anpei.org.br.

BARBIERI, J.C. (Ed.) (2004) Organizações inovadoras: Estudos e casos brasileiros. Editora FGV, Rio de Janeiro.

BARDIN, L. (1977). Análise de conteúdo. Persona Edições, Lisboa.

BERKUN, S. (2010). The Mith of Innovation. O'Reilly Books, Canada.

BURNS, T., Stalker, G. (1961). The Management of Innovation. Tavistock, London.

CANDIDO, G. A., Oliveira, J. N. (2007). Características e práticas gerenciais de empresas inovadoras. Revista Fonte. Minas Gerais. 5, Janeiro, 65-72.

CHRISTENSEN, C. (200I). O dilema da inovação. Makron Books, São Paulo.
DAFT, R. L., Marcic, D. (2004). Understanding management. $4^{\text {th }}$ edition. Thomson South Western, Mason.

FIATES, G. G. S. (200I) Avaliação de ferramentas da internet para apoiar o desenvolvimento de organizações de aprendizagem. Tese (Doutorado em Engenharia da Produção) - Universidade Federal de Santa Catarina, Florianópolis.

FOGUEL, S., Souza, C. C. (1985). Desenvolvimento organizacional. $2^{\text {nd }}$ edition. Ed Atlas, São Paulo.

HAMEL, G.. (2000) Liderando a revolução. Campus, Rio de Janeiro.

HIGGINS, J.M. (1995) Innovate or evaporate - Test \& improve your organizations. I.Q. Its Innovation Quotient. New Management Publishing Company, New York.

JANOV, J. (1996). A organização inventiva: Ousadia e dedicação no trabalho. Ediouro, Rio de Janeiro.

KOTLER, P., Keller, K.L. (2005). Marketing management, 12th edn. Prentice Hall, Boston, MA.

LANE, J.A., Bohem, B., Bolas, M., Madni, A., Turner, R. (2010). Critical Success Factors for Rapid, Innovative Solutions. P. 52-6I. In: Munch, J., Yang, Y., Schafer, W. (Eds). New Modeling Concepts for Today's Software Processes. ICSP, 2010. Springer Ed. Germany.

LEONARD-BARTON, D. (1998). Nascentes do saber: Criando e sustentando as fontes de inovação. Editora FGV, Rio de Janeiro.

LUNDVALL, B. A. (ed.) (1992). National systems of innovation: Towards a theory of innovation and interactive learning. Pinter Publ. London.

MACIEL, M. L. (1996). O milagre italiano: Caos, crise e criatividade. Paralelo I5, Brasília.

MACULAN, A.M. (2003) Ambiente empreendedor e aprendizado das pequenas empresas de base tecnológica. In: Lastres, H.M.M., Cassiolatto, J. E., Maciel, M. L. Pequena empresa: Cooperação e desenvolvimento local. Relume Dumará, UFRJ, Rio de Janeiro. pp. 3। I-326.

MACULAN, A.M, Vinhas, V.Q, Faria, R.F.F, Guedes, M. (2002). Reflexões sobre o desempenho inovador das 
empresas graduadas. Anais do XXII Simpósio de Gestão da Inovação Tecnológica, Bahia.

MALACHIAS, C. de S., Meirelles, D. S. (2009). Regime Tecnológico, Ambiente de Inovação e Desempenho Empresarial no Setor de Serviços: Um Estudo Exploratório das Empresas de Tecnologia da Informação. RAI - Revista de Administração e Inovação, São Paulo, 6(2), 58-80.

MENDEL, N. M. F. (2004). Estratégia empresarial e inovação organizacional: Um estudo de caso na Brasil Telecom. Dissertação de Mestrado. Programa de Pós Graduação em Administração e Negócios, PUC, RS.

MERRIAM, S. (1998). Qualitative research and case study applications in Education. Jossey-Bass, San Francisco.

MINTZBERG, H, Ahlstrand, B, Lampel, J. (2000). Safári de estratégias: Roteiro pela selva do planejamento estratégico. Bookmann, Porto Alegre.

MINTZBERG, H., Quinn, J. B. (200I). O processo da estratégia. Editora Bookman, Porto Alegre.

MOTTA, P.R. (200I). Transformação Organizacional: a teoria e a prática de inovar. Qualitymark, RJ.

NEELY, A., Hii, J. (1998). Innovation and Business performance: a literature review. Government Office of the Eastern Region. University of Cambridge, Cambridge.

NIDUMOLU, R., Prahalad, C.K., Rangaswami, M.R. (2009). Why Sustainability Is Now the Key Driver of Innovation. Harvard Business Review, September, 57-64.

NONAKA, I., Takeuchi, H. (1997). Criação de conhecimento na empresa: Como as empresas japonesas geram a dinâmica da inovação. Campus, Rio de Janeiro.

OKSANEN, J., Rilla, N. (2009). Innovation and Entrepreneurhip: New Innovations as Source For Competitiveness in Finnish SMES. International Journal of Entrepreneurship, 13, Special Issue, 35-47.

PINHO, M., Côrtes, M.R., Fernandes, A.C. (2002). A fragilidade de empresas de base tecnológica em economias periféricas: uma interpretação baseada na experiência brasileira. Ensaios FEE, 23(I), 135-162.
PNI - Programa Nacional de Apoio às Incubadoras de Empresas e Parques Tecnológicos - Available at http://www.mct.gov.br/index.php/content/view/5228.html

[Accessed in 15/03/2007].

QUINN, J. B. (1985). Managing innovation: Controlled chaos. Harvard Business Review, May - June, 73-84.

RAMOS, A. G. (1983). Administração e contexto brasileiro: Esboço de uma teoria geral de administração. $2^{\mathrm{a}}$ Ed. FGV, Rio de Janeiro.

SAWHNEY, M., Wolcott, R. C. (2006). The 12 Different ways for companies to innovate: Management of technology and innovation. MIT Sloan Management Review. Spring, 47(3), 75-8I.

SCHEIN, E. H. (1986). Organization culture and leadership. Jossey-Bass, San Francisco.

SENGE, P. (1997). O novo trabalho do líder: Construindo organizações que aprendem. In: Sarkey, K. (Ed.). Como as organizações aprendem. Futura, São Paulo. pp. 342-375.

SLUIS, L. E. C. V. (2004). Designing the workplace for learning and innovation. Developing and Learning Organizations. 18(5), 10-13.

STARKEY, K. (ed.) (1997). Como as organizações aprendem. Futura, São Paulo. pp. 342-375.

TIDD, J., Bressant, Jr., Pavitt, K. (200I). Managing innovation: Integrating technological, market and organizational change. $2^{\text {nd }}$ edition. Inglaterra.

TUCKER, R.B. (2002) Driving growth through innovation: how leading firms are transforming their futures. BerretKoehler, California.

TUSHMAN, M. L., Nadler, D. A. (1997). Executive excellence. Provo, I5(8), 2I-23. 